\title{
INSTRUMENTS AND METHODS A NEW DRY EXTRACTION SYSTEM FOR GASES IN ICE
}

\author{
By Ernst Moor and Bernhard Stauffer
}

(Physikalisches Institut, Universität Bern, Sidlerstrasse 5, CH-3012 Bern, Switzerland)

\begin{abstract}
A new extraction system has been designed and constructed which allows the extraction of gases from air bubbles in ice without melting it. The ice sample of about $500 \mathrm{~g}$ is crushed in an evacuated container by a milling cutter, and the gas escaping from the opened bubbles is collected by condensation at $15 \mathrm{~K}$. Results of $\mathrm{CO}_{2}$ analyses of extracted gases are discussed with respect to possible contamination risks by the system.
\end{abstract}

RÉsumé. Un nouveau système d'extraction à sec des gaz contenus dans la glace. Un nouveau système d'extraction a été étudié et réalisé qui permet l'extraction des gaz à partir des bulles contenues dans la glace sans la fondre. L'échantillon de glace pesant environ $500 \mathrm{~g}$ est découpé dans une enceinte sous vide par fraisage et le gaz s'échappant des bulles est recueilli par

\section{INTRODUCTION}

The gas composition of air bubbles in ice which was formed by dry sintering is to a good approximation atmospheric. Al ready Scholander and others (1961) have analysed air extracted from ice samples with Known or estimated age to study the history of atmospheric gas composition. Reliable results, especially concerning the $\mathrm{CO}_{2}$ concentration, were only obtained after ice samples from very cold regions were selected and after dry extraction techniques had been applied (Berner and others, 1980; Delmas and others, 1980). According to measurements with these techniques on such samples, the $\mathrm{CO}_{2}$ concentration shows several significant variations during the past 40000 years. It is of great interest to study in parallel with the $\mathrm{CO}_{2}$ concentration other trace gases and the ${ }^{13} \mathrm{C} /{ }^{12} \mathrm{C}$ ratio of the $\mathrm{CO}_{2}$ in the extracted air. Measurements for these purposes require a minimal sample size of about $500 \mathrm{~g}$ of ice. Up to now, no dry extraction system for such large samples has been available.

Although dry extraction methods drastically reduce contamination by $\mathrm{CO}_{2}$ formed from carbonates, there remains the risk of a smaller contamination by gases desorbed from the walls of the extraction system. In particular $\mathrm{CO}_{2}$ desorption depends on the water-vapour pressure (Zumbrunn and others, 1982) and shows an almost linear increase with the extraction time. There is also the possibility of losing gas by adsorption on newly formed surfaces of crushed or ground ice (0campo and K1 inger, 1982).

To minimize these risks of contamination by desorption and of loss by adsorption, the gases have to be extracted at low temperature (and therefore low water-vapour pressure), the extraction time must be kept short, and the surface area of crushed ice should be minimal.

We met these conditions by constructing an extraction system based on a milling cutter working at $-20^{\circ} \mathrm{C}$, which allows us to crush a sample of $500 \mathrm{~g}$ of ice in only 2 min into chips of approximately $1 \mathrm{~mm}^{3}$. The air from the bubbles is collected by condensation at $15 \mathrm{~K}$ in less than $10 \mathrm{~min}$.

\section{DESCRIPTION OF THE EXTRACTION SYSTEM}

\section{Principle}

The extraction system is schematically shown in Figure 1. It consists mainly of a crushing device, condensation à $15 \mathrm{~K}$. Des résultats d'analyses de $\mathrm{CO}_{2}$ de gaz ainsi extraits sont discutés par rapport aux risques d'une contamination possible due au système.

Zusammenfassung. Ein neues Trockenextraktionssystem für Gase in Eis. Ein neuentwickeltes Extraktionssystem erlaubt, die in den Luftblasen des Eises eingeschlossenen Gase ohne Schmelzen zu extrahieren. Eine Eisprobe von ungefähr $500 \mathrm{~g}$ wird in einem evakuierten Behälter mit einem Fräser zerkleinert. Die aus den geöffneten Blasen entweichenden Gase werden bei $15 \mathrm{~K}$ kondensiert. Resultate von $\mathrm{CO}_{2}$-Analysen an extrahierten Luftproben werden im Hinblick auf mögliche Kontaminationen durch das System diskutiert.

which by milling the ice sample opens the air bubbles, and a gas collection device.

\section{crushing device}

The ice sample is crushed in an evacuated container by a milling cutter. The milling cutter is driven by magnetic coupling with a crank outside the evacuated container, so that any dynamic vacuum seals can be avoided. All parts which may get into contact with the ice samples or the extracted air are made from stainless steel. The different parts are sealed by metal gaskets. Gold is used for permanent seals, aluminium for seals which have to be replaced after each extraction. The milling cutter runs in greaseless silver-coated ball bearings. The ice sample is pressed against the milling cutter by its own weight plus an additional force exerted form the outside with the help of a second magnetic coupling. This coupling allows the force to be adjusted during the milling process. The size of the ice chips varies within certain limits, depending on the applied force. The permanent magnets inside the evacuated container (for the milling cutter and the sample feed) are packed in stainless steel. The crushing device is operated in a cold room at $-20^{\circ} \mathrm{C}$.

\section{Gas collection device}

The gas extracted from the opened bubbles is collected by condensation at $15 \mathrm{~K}$ in a small gassample container cooled by a helium closed-cycle refrigerator, Leybold Heraeus CRYOGEN R210. Water vapour is removed by a cold trap, located between the crushing device and the gas-sample container and cooled with liquid nitrogen. With an adjustable heater the temperature of the cold trap can be regulated between $-196^{\circ} \mathrm{C}$ and $-40^{\circ} \mathrm{C}$, for the measurements presented here it was operated at $-80^{\circ} \mathrm{C}$. The duration of an extraction is determined by the condensation time of the gases and not by the time needed to crush the ice. In Figure 2 a typical pressure-decrease diagram during collection of $54 \mathrm{~cm}^{3}$ of gas at S.T.P. is shown.

\section{Extraction procedure}

To insert an ice sample into the crushing device, the evacuated apparatus is flushed with $\mathrm{CO}_{2}$-free nitrogen before opening the cover. The ice sample is lowered slowly into the sample container attached to a metal wire, which is removed after the sample is in place on top of the milling cutter. The inner part of the sample feed coupling is inserted. Afterwards 


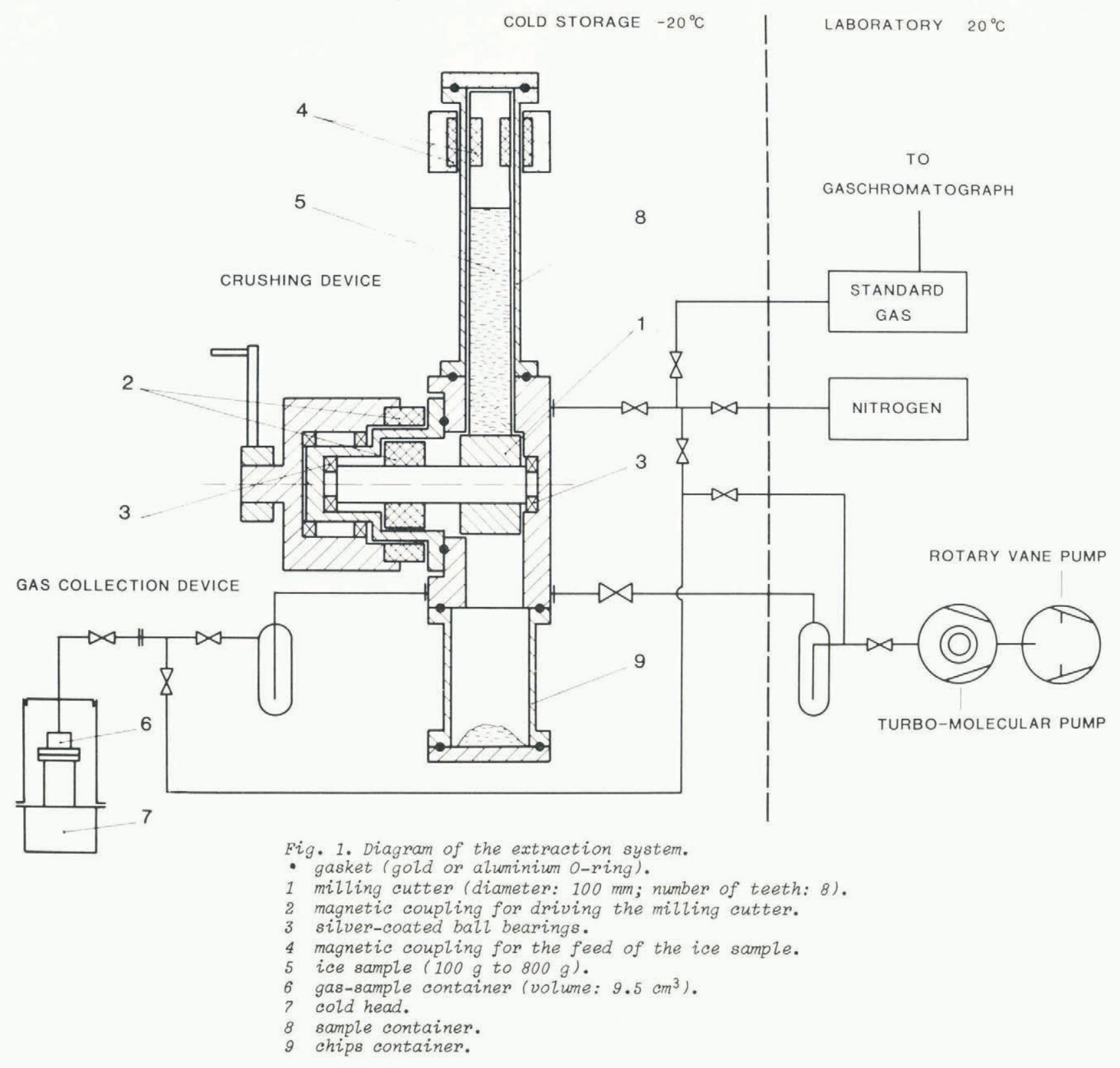

the sample container is sealed vacuum-tight with an aluminium 0-ring. The extraction device is then evacuated to the dynamic pressure of water vapour of about $30 \mathrm{~Pa}$, and pumping is continued at this pressure for at least one hour to remove possible impurities adsorbed at the ice surface. After that the crushing device is closed off from the vacuum pump and the valve to the evacuated small gas-sample container, which has already been cooled down to $15 \mathrm{~K}$, is opened. Milling is now started. With the milling cutter working at a rate of about 1-2 revolutions per second, a sample of $500 \mathrm{~g}$ is crushed in about $2 \mathrm{~min}$. Collection of gases has to be continued for approximately 10 min to avoid losses by incomplete condensation.

The total efficiency of the extraction is about $90 \%$, if we assume that the total air content in ice from South Pole is $90.3 \mathrm{~cm}^{3}$ S.T.P. $\mathrm{kg}^{-1}$, calculated according to Raynaud and Whillans (1982). Most of the remaining gas is still trapped in bubbles which were not opened during crushing. We estimate that only a minor part of the losses is due to incomplete condensation.

After the crushing process, the crushing device is again flushed with $\mathrm{CO}_{2}$-free nitrogen, and the chips container is opened to remove the crushed ice.
Test results

Tests were made by analyzing fractions of the extracted and collected gas using a gas chromatograph, Hewlett Packard 5880 A. To estimate the order of magnitude of the contamination by $\mathrm{CO}_{2}$ from leaks and especially by desorption of $\mathrm{CO}_{2}$ from the walls of the system, we made some tests with bubble-free single crystals, which were grown from super-pure water as described by Schwander and others (1983). The extraction procedure with single crystals is identical to that with an ordinary ice sample, except that about $30 \mathrm{~cm}^{3}$ S.T.P. of either $\mathrm{CO}_{2}$-f ree nitrogen or a $\mathrm{CO}_{2}$ standard gas mixture are added into the ice sample container before milling is started. The results of the analyses of the collected gas samples are shown in Table I. They indicate that contamination by $\mathrm{CO}_{2}$ is of the order of magnitude of 1 p.p.m., as long as the extraction time is kept short. Only for the sample with an extrction time more than ten times normal was a much higher $\mathrm{CO}_{2}$ concentration measured.

A second series of tests was made with samples from an ice core drilled by PICO in 1982 at the South Pole (Kuivinen, 1983) (Table II). The samples are from a depth below the surface of between $160 \mathrm{~m}$ and $220 \mathrm{~m}$ corresponding to an age of the enclosed 
TABLE I. RESULTS OF TESTS WITH BUBBLE-FREE SINGLE ICE CRYSTALS. THE STANDARD GAS ADDED IS ALSO USED TO CALIBRATE THE GAS-CHROMATOGRAPH

\begin{tabular}{|c|c|c|c|c|c|c|}
\hline \multirow[t]{2}{*}{$\begin{array}{l}\text { Sample } \\
\text { number }\end{array}$} & $\begin{array}{l}\text { Sample } \\
\text { size }\end{array}$ & \multicolumn{2}{|c|}{$\begin{array}{l}\text { Gas added } \\
\text { to ice } \\
\text { sample }\end{array}$} & \multirow{2}{*}{$\begin{array}{c}\text { Total time } \\
\text { gas in the } \\
\text { system } \\
\text { min }\end{array}$} & \multirow{2}{*}{$\begin{array}{c}\text { Collection } \\
\text { time } \\
\text { min }\end{array}$} & \multirow{2}{*}{$\begin{array}{c}\mathrm{CO}_{2} \text { concen- } \\
\text { tration in } \\
\text { collected gas } \\
\text { p.p.m. }\end{array}$} \\
\hline & $\mathrm{g}$ & & $\pi^{3}$ S.T.P. & & & \\
\hline 10 & 107 & 30.4 & $\begin{array}{l}\text { standard gas } \\
319 \mathrm{ppm} \mathrm{CO}_{2}\end{array}$ & 17 & 13 & $320.4 \pm 2.0$ \\
\hline 11 & 67 & 17.3 & $\begin{array}{l}\text { standard gas } \\
319 \mathrm{ppm} \mathrm{CO} 2\end{array}$ & 250 & 15 & $346.0 \pm 1.5$ \\
\hline 25 & $\begin{array}{l}200 \\
\text { sample not } \\
\text { crushed }\end{array}$ & 32.5 & $\begin{array}{l}\text { nitrogen } \\
\mathrm{CO}_{2} \text {-free }\end{array}$ & 14 & 10 & $0.4 \pm 0.1$ \\
\hline 26 & 85 & 32.9 & $\begin{array}{l}\text { nitrogen } \\
\mathrm{CO}_{2} \text {-free }\end{array}$ & 26 & 10 & $1.1 \pm 0.2$ \\
\hline
\end{tabular}

TABLE II. SOUTH POLE STATION ICE CORE. $\mathrm{CO}_{2}$ CONCENTRATION IN AIR BUBbLES

\begin{tabular}{|c|c|c|c|c|c|c|}
\hline $\begin{array}{l}\text { Sample } \\
\text { number }\end{array}$ & $\begin{array}{c}\text { Depth of sample } \\
\mathrm{m}\end{array}$ & $\begin{array}{l}\text { Sample } \\
\text { size } \\
\mathrm{g}\end{array}$ & $\begin{array}{l}\text { Amount of } \\
\mathrm{cm}^{3} \text { S.T.P }\end{array}$ & $\begin{array}{l}\text { collected air } \\
\text { P. per } \mathrm{kg} \text { ice }\end{array}$ & $\begin{array}{c}\mathrm{CO}_{2} \\
\text { concentration } \\
\text { p.p.m. }\end{array}$ & Remarks \\
\hline 20 & $161.35-161.81$ & 708 & & 83 & $284.1 \pm 5.0$ & \\
\hline 28 & $183.50-184.02$ & 712 & & 76 & $284.5 \pm 3.0$ & \\
\hline 30 & $191.21-191.50$ & 440 & & 66 & $274.4 \pm 2.0$ & gas collection time: $2 \mathrm{~min}$ \\
\hline 31 & $191.71-192.06$ & 450 & & 77 & $282.4 \pm 2.5$ & gas collection time: 40 min \\
\hline 32 & $206.22-206.72$ & 382 & discs a & $\begin{array}{l}37 \\
\text { are broken }\end{array}$ & $283.4 \pm 3.0$ & $\begin{array}{l}\text { sample cut into discs, sur- } \\
\text { face increased by a factor } \\
\text { of two }\end{array}$ \\
\hline 33 & $215.40-215.90$ & 572 & & 67 & $282.4 \pm 2.0$ & ice crushed to coarse chips \\
\hline 34 & $159.85-160.35$ & 578 & & 84 & $282.8 \pm 2.0$ & pumping time: 30 min \\
\hline 35 & $171.55-172.05$ & 333 & & 12 & $268.1 \pm 3.0$ & gas collection time: $20 \mathrm{~s}$ \\
\hline
\end{tabular}
Pumping time after filling of an ice sample is approximately $4 \mathrm{~h}$, gas collection time $10 \mathrm{~min}$, if not stated other-
wise.

air of about 400 to 1000 years. Several parameters were varied during the extraction procedure to investigate if these parameters have any influence on the composition of the extracted gas. There seems to be no difference whether we crush the ice to fine or coarse chips, or whether we start with an ice sample in one piece or with one cut into several discs, thus increasing the surface. Values of the $\mathrm{CO}_{2}$ concentration which are too low, compared to the mean value, are observed if the condensation time is kept below 10 min (samples no. 30 and no. 35, Table II).

If samples no. 30 and no. 35 are excluded, the mean value of the $\mathrm{CO}_{2}$ concentration is $283.3 \pm 0.8$ p.p.m. This value is about 20 p.p.m. higher than the mean value measured on samples of $1 \mathrm{~g}$ from this ice core using an infrared laser-absorption spectrometer in combination with a small crusher described by Zumbrunn and others (1982).*

* Measurements made after submission of this paper point to a systematic deviation in the analysis of the $1 \mathrm{~g}$ samples. During expansion of the sample gas from the crusher into the laser absorption spectrometer, $\mathrm{CO}_{2}$ is depleted, a risk which is not inherent in the new system. The values obtained with this new system seem, therefore, to be more reliable.

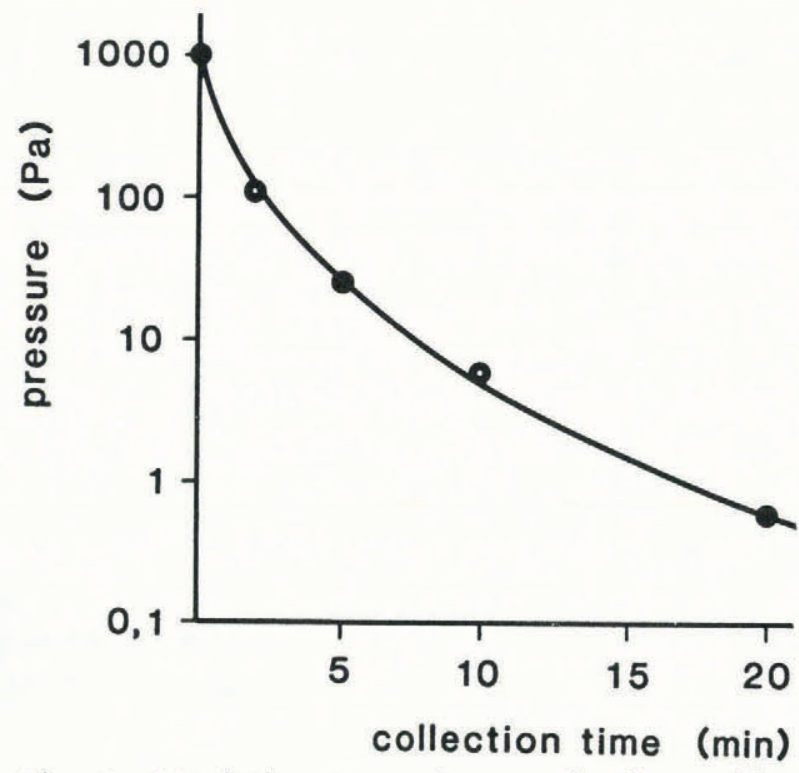

Fig. 2. A typical pressure decrease in the crushing device during gas collection in a test run. $54 \mathrm{~cm}^{3}$ STP of standard gas, but no ice, were filled into the crushing device. 
The difference is due to differences in the extraction and not in the gas analysis methods, but the detailed reasons for it are not yet known, and it is not clear which of the values is correct. The results in Table II show, however, that the new extraction method leads to results which are reproducible and show a very low scatter.

\section{ACKNOWLEDGEMENTS}

The dry extraction system was developed in the course of a research program directed by $H$. Oeschger and supported by the Swiss National Science Foundation. We would like to thank A. Neftel, M. Möll, and $J$. Schwander for valuable discussions, and H. Frick, F. Hosner, M. Läuffer, S. Studer, $M$. Stucki, and H. Riesen for the manufacture of the system.

\section{REFERENCES}

Berner, W., and others. 1980. Information on the $\mathrm{CO}_{2}$ cycle from ice core studies, by W. Berner, H. Deschger, and B. Stauffer. Radiocarbon, Vol. 22, No. 2 , p. 227-35.
Delmas, R.J., and others. 1980. Polar ice evidence that atmospheric $\mathrm{CO}_{2} 20,000 \mathrm{yr}$ BP was $50 \%$ of present, by R.J. Delmas, J.-M. Ascencio, and M. Legrand. Nature, Vol. 284, No. 5752, p. 155-57.

Kuivinen, K.C. 1983. A $237-m$ ice core from South Pole station. Antarctic Journal of the United States, Vol. 18 , No. 5 , p. 113-14

0campo, J., and $\mathrm{Kl}$ inger, J. 1982. Adsorption of $\mathrm{N}_{2}$ and $\mathrm{C}_{2}$ on ice. Journal of Colloid and Interface Science, Vol. 86, No. 2, p. 377-83.

Raynaud, D., and Whillans, I.M. 1982. Air content of the Byrd core and past changes in the West Antarctic ice sheet. Annals of Glaciology, Vol. 3, p. 269-73.

Scholander, P.F., and others. 1961. Composition of gas bubbles in Greenland icebergs, by P.F. Scholander, E.A. Hemmingsen, L.K. Coachman, and D.C. Nutt.

Journal of Glaciology, Vol. 3, No. 29, p. 813-22.

Schwander, J., and others. 1983. Measurement of a DCconductivity on ice samples for climatological applications, by J. Schwander, A. Neftel, H. Oeschger, and B. Stauffer. Journal of Physical Chemistry, Vol. 87 , No. 21 , p. 4157-60.

Zumbrunn, R., and others. 1982. $\mathrm{CO}_{2}$ measurements on $1-\mathrm{cm}^{3}$ ice samples with an IR laserspectrometer (IRLS) combined with a new dry extraction device, by R. Zumbrunn, A. Neftel, and H. Oeschger. Earth and Planetary Science Letters, Vol. 60, №. 2, p. 31824. 